\title{
INDUCTION OF DEFENSE MECHANISMS IN TOMATO PLANTS BY SAPROBIC FUNGI FILTRATES AGAINST EARLY BLIGHT DISEASE ${ }^{1}$
}

\author{
MARIANNA SANTOS RODRIGUES ALENCAR ${ }^{2}$, ANTÔNIO JUSSIÊ DA SILVA SOLINO ${ }^{*}$, JULIANA SANTOS \\ BATISTA OLIVEIRA ${ }^{2}$, SÉRGIO FLORENTINO PASCHOLATI ${ }^{4}$, KÁTIA REGINA FREITAS SCHWAN-ESTRADA ${ }^{2}$
}

\begin{abstract}
Tomato plants can be attacked by several diseases. The early blight disease causes large losses to tomato growers and requires many applications of fungicide for its control. Thus, the objective of this work was to evaluate the effect of saprobic fungi filtrates on the control of early blight (Alternaria solani) in tomato plants. The treatments consisted of fungi filtrates (Stachylidium bicolor - SBI; Periconia hispidula - PHI; Brachysporiella pulchra - BPU; Myrothecium leucotrichum - MLE; and Pycnoporus sanguineus - PSA) diluted at 20\%, a control (water), and acibenzolar-S-methyl (ASM). Tomato plants with five leaves were treated with the filtrates, and $A$. solani was inoculated after three days. The variables analyzed were: area under the disease progress curve (AUDPC), and specific activity of the enzymes: catalase, lipoxygenase, peroxidase, and polyphenol oxidase. The SBI filtrate decreased the AUDPC in $80 \%$ for the third leaf and $96 \%$ for the fourth leaf. Catalase activity increased due to the application of $B P U$ and $P H I$ filtrates, at 96 hours post-inoculation (hpi). Lipoxygenase activity increased in $130 \%, 72 \%, 130 \%$, and $81 \%$ at 24 hpi when applying the $S B I, P H I$, $M L E$, and ASM filtrates, respectively. The application of SBI, BPU, MLE, and PSA filtrates increased lipoxygenase activity in $30 \%, 26 \%, 12 \%$, and $22 \%$, respectively, at 120 hpi. Peroxidase activity increased $74 \%$ at $120 \mathrm{hpi}$, when applying the $S B I$ filtrate. Polyphenol oxidase activity was not affected by the treatments. $S$. bicolor filtrate is efficient to control the severity of the early blight disease in tomato plants.
\end{abstract}

Keywords: Alternaria solani. Alternative control. Resistance induction.

\section{INDUÇÃO DE MECANISMO DE DEFESA DE TOMATEIRO POR FILTRADOS DE SAPRÓBIOS NO CONTROLE DA PINTA PRETA}

RESUMO - O tomateiro pode ser atacado por diversas doenças, como a pinta preta, que causa grandes prejuízos aos produtores, exigindo grande número de aplicações de fungicidas. Assim, o objetivo deste trabalho foi avaliar o efeito de filtrados de fungos sapróbios no controle de pinta preta do tomateiro (Alternaria solani). Os tratamentos foram constituídos por filtrados de Stachylidium bicolor (SBI), Periconia hispidula (PHI), Brachysporiella pulchra (BPU), Myrothecium leucotrichum (MLE) e Pycnoporus sanguineus (PSA) diluídos a $20 \%$, além da testemunha (água) e acibenzolar-S-metil (ASM). As plantas de tomate, com cinco folhas, foram pulverizadas com filtrados e três dias após realizou-se a inoculação com $A$. solani. As variáveis analisadas foram a área abaixo da curva de progresso da doença (AACPD) e a atividade específica de catalase, lipoxigenases, peroxidase e polifenoloxidase. A aplicação de filtrado de SBI promoveu redução de $80 \%$ e $96 \%$ da AACPD na terceira e quarta folha respectivamente. A catalase foi incrementada com uso dos filtrados de BPU e PHI 96 hpi. A lipoxigenase foi incrementada 130, 72, 130 e 81\% no horário 24 hpi ao aplicar os filtrados de SBI, PHI, MLE e ASM respectivamente. Os filtrados de SBI, BPU, MLE e PSA incrementaram a atividade da lipoxigenase em 30,26, 12 e 22\% respectivamente, no horário 120 hpi. A atividade de peroxidase aumentou 74\% em função da aplicação de SBI 120 hpi. A polifenoloxidase não foi influenciada pelos tratamentos. O filtrado de S. bicolor é efetivo em promover o controle da severidade da pinta preta do tomateiro.

Palavras-chaves: Alternaria solani. Controle alternativo. Indução de Resistência.

\footnotetext{
${ }^{*}$ Corresponding author

${ }^{1}$ Received for publication in 09/13/2019; accepted in 04/29/2020.

Paper extracted from the master's thesis of the first author

${ }^{2}$ Department postgraduate of Agronomy, Universidade Estadual de Maringá, Maringá, PR, Brazil; mariannarodrigues86@hotmail.com ORCID: 0000-0001-5894-554X, julianaglomer@hotmail.com - ORCID: 0000-0002-1260-4341, krfsestrada@uem.br - ORCID: 0000-0001 $-8384-8557$.

${ }^{3}$ Department of Agronomy, Universidade de Rio Verde, Rio Verde, GO, Brazil; antoniosolino@unirv.edu.br - ORCID: 0000-0001-59229983.

${ }^{4}$ Phytopathological Physiology and Biochemistry Laboratory, Universidade de São Paulo, São Paulo, SP, Brazil; sfpascho@usp.br ORCID: 0000-0002-9690-9694.
} 


\section{INTRODUCTION}

Tomato has one of the most expressive agricultural productions in the world and is an important product for fresh and processed food markets. Brazil is the tenth largest tomato producing country, with a production of $4,230,150 \mathrm{Mg}$, presenting average yields higher than the world average (FAOSTAT, 2019).

Diseases are an important factor that decreases yield and number of fruits in tomato crops. The early blight disease, which is caused by Alternaria solani, is recurrent in all producing regions and compromises the fruit marketing (AMORIM et al., 2011; JONES, 1991). This disease causes stem cancer in seedlings, which is characterized by dark-brown circular spots that evolve and form concentric rings in leaves and branches, resulting in defoliation and, in severe cases, it exposes the fruits to sun burning; in addition, the infection of this pathogen causes spots and rotting in fruits (AMORIM et al., 2011)

The high aggressivity of early blight disease in tomato plants demands high frequency of fungicide applications, which present higher availability and efficiency and rapid results (DEISING; REIMANN; PASCHOLATI, 2008; FISHER et al., 2018). Inappropriate concentration of chemical products used for disease control is responsible for emergence of resistant pathogens, and for permanence of toxic residues in the environment and in fruits to be marketed (BRENT, 2007; FONSECA et al., 2007). Landschoot et al. (2017) evaluated 83 isolates of $A$. solani and found substitutions of amino acids in different subunits of the gene of the succinate dehydrogenase, which is the acting site of the boscalid active principle used to control early blight disease, with $70 \%$ transmission of the mutation regarding resistance to this chemical molecule to their descendants. Thus, alternative control of plant diseases can be associated to chemical, genetic, and cultural managements, which contribute to reducing the use of chemical products and increasing agricultural yields.

Induction of resistance is among the alternative control measures that involve the activation of latent defense mechanisms of plants by biotic or abiotic inducers, and has been widely studied because of its efficiency (THAKUR et al., 2019; WALTERS; RATSEP; HAVIS, 2013; HAMMERSCHMIDT; MÉTRAUX; VAN LOON, 2001). Active mechanisms include proteins, such as the activity of catalase, phenylalanine ammonialyase, lipoxygenase, peroxidase, polyphenol oxidase, and $\beta$-1.3-glucanase (KIRÁLY; BARNA; KIRÁLY, 2007; DUBERY; SANABRIA; HUANG, 2012).

Products of metabolism of microorganisms are sources of molecules with potential to control plant diseases by antimicrobial action and activation of latent defense mechanisms of plants to pathogens (PEITL et al., 2017; SOLINO et al., 2016; ZEILINGER et al., 2016). Bae et al. (2016) evaluated bioprospection of metabolites of 128 fungi isolates and found that the Trichoderma virens (KACC 40929) decreased the severity of Phytophthora capsici in tomato and pepper plants in up to $60 \%$, induced expression genes related to defense, and increased abscisic and salicylic acid concentrations in their leaves, which are involved in defense responses of plants.

Considering the diversity of organisms with potential to produce bioactive molecules, the objective of this work was to evaluate the effect of saprobic fungi filtrates on the control of early blight (Alternaria solani) in tomato plants by induction of resistance mechanisms, using isolates from the Semiarid region of the Northeast of Brazil.

\section{MATERIAL AND METHODS}

The experiment was conducted in a greenhouse of the Department of Agronomy of the Maringá State University (UEM; Maringá, PR, Brazil) to evaluated the control early blight disease.

\section{Filtrates of isolates of saprobic fungi}

The saprobic fungi isolates (Stachylidium bicolor, Periconia hispidula, Brachysporiella pulchra, and Myrothecium leucotrichum) were provided by the Feira de Santana State University (Biodiversity Research Program; PPBio); and the Pycnoporus sanguineus isolate was provided by the State University of Western Paraná. They were maintained in batata dextrose agar (BDA) medium at $25 \pm 2{ }^{\circ} \mathrm{C}$ and 12 -hour photoperiod. The filtrate was obtained using a $7 \mathrm{~mm}$ diameter disc of colonies of saprobic fungi for each $100 \mathrm{~mL}$ of BDA, placed in an Erlenmeyer, and maintained in the dark in a growth chamber at $25 \pm 2{ }^{\circ} \mathrm{C}$ for 20 days (PAZUCH, 2007). The liquid mediums containing the saprobic fungi were then filtrate in Whatman paper (no. 1) to separate the liquid fraction from the mycelium. A second filtering was done in a Millipore system, through a membrane with $0.45 \mu \mathrm{m}$ diameter pores, to sterilize the extract.

\section{Obtaining of the pathogen}

The phytopathogen $A$. solani was obtained from tomato leaves that exhibited characteristic symptoms of the disease. They were isolated in agarwater medium and, subsequently, replicated in a BDA medium and maintained at $28{ }^{\circ} \mathrm{C}$ with 12 -hour photoperiod to obtain pure colonies, which were maintained in the same conditions. 


\section{Greenhouse experiment}

The effect of different saprobic fungi filtrates was evaluated on tomato plants of the cultivar Santa Cruz Kada, grown in plastic pots containing $5 \mathrm{~L}$ of a non-autoclaved substrate consisted of soil and sandy $\left(3: 1 \mathrm{v} \mathrm{v}^{-1}\right)$. The treatments presented in Table 1 were applied weekly up to the slide point, when the plants had five totally expanded leaves, totaling three applications. A completely randomized experimental design was used, with 7 treatments and 5 replications.

Table 1. Treatments used in the control of early blight (Alternaria solani) in tomato plants.

\begin{tabular}{lcc}
\hline \multicolumn{1}{c}{ Treatments } & Code & Concentration \\
\hline Control (water) & - & - \\
Stachylidium bicolor filtrate & $S B I$ & $20 \%$ \\
Periconia hispidula filtrate & $P H I$ & $20 \%$ \\
Brachysporiella pulchra filtrate & $B P U$ & $20 \%$ \\
Myrothecium leucotrichum filtrate & $M L E$ & $20 \%$ \\
Pycnoporus sanguineus filtrate & $P S A$ & $20 \%$ \\
Acibenzolar-S-methyl & ASM & $5 \mathrm{~g} \mathrm{ll}^{-1}$ \\
\hline
\end{tabular}

After the third application of the treatments, Alternaria solani was inoculated at concentration of $1 \times 10^{-4}$ conidia $\mathrm{mL}^{-1}$. This suspension was obtained from pure colonies grown on Petri dishes, in which was added distilled water and Tween $(0.1 \%)$; a Drigalski loop was used to scratch and release the conidia; then, the solution was filtrated in gauze and placed in a Neubauer chamber.

The inoculation consisted in spraying the $A$. solani suspension on leaves of plants at 24 hours after the last application of treatments, and maintaining them in a moist chamber for 12 hours. The severity of the disease was evaluated on the third and fourth leaves of the plants at 4, 8, 12, 16, and 20 days after the inoculation, using the diagrammatic scale developed by Boff (1988). The disease severity evaluation data were used to calculate the area under the disease progress curve (AUDPC) (CAMPBELL; MADDEN, 1990), using Equation 1.

$$
A U D P C=\sum_{i}^{n-1}\left[\left(\frac{y_{i}+y_{i+1}}{2}\right)\left(t_{i+1}-t_{i}\right)\right] \quad 1
$$

where $n$ is the number of evaluations, $y i$ and $y i+1$ are the severity values recorded in two consecutive evaluations, and $t i+1-t i$ is the interval between evaluations.

The biochemical analyses were carried out at $0,24,48,72,96$, and 120 hours after the inoculation, using leaflets of the fourth leaf. The leaf samples were placed in foil envelopes and stored at $-20^{\circ} \mathrm{C}$ up to processing to obtain the enzymatic extract, which consisted of maceration and homogenization of the plant tissue samples in $4 \mathrm{~mL}$ sodium phosphate buffer $0.01 \mathrm{M}$ ( $\mathrm{pH} 6.0$ ), followed by a centrifugation at $6,500 \mathrm{~g}$ at $4{ }^{\circ} \mathrm{C}$ for 30 minutes. The supernatant was collected and used as enzymatic extract to determine total protein content in the specific activities of catalase, lipoxygenase, peroxidase of guaiacol, and polyphenol oxidase (SOLINO et al.,

\section{6; BALBI-PEÑA; SCHWAN-ESTRADA;} STANGARLIN, 2014).

Total protein was quantified by the method described by Bradford (1976). Absorbance values were plotted in a standard curve of concentrations of bovine serum albumin, and the results were expressed in $\mu \mathrm{mg}$ protein $\mathrm{mL}^{-1}$. It was subsequently used to calculate the specific activity of the following enzymes: catalase, lipoxygenase, peroxidase guaiacol, and polyphenol oxidase.

The catalase activity (EC 1.11.1.16) was quantified by the method described by Goth (1991) and modified by Tománková et al. (2006). The enzymatic extract $(0.1 \mathrm{~mL})$ was incubated in $0.5 \mathrm{~mL}$ of a reaction mixture containing $60 \mathrm{mM}$ of hydrogen peroxide $\left(\mathrm{H}_{2} \mathrm{O}_{2}\right)$, in potassium phosphate buffer 60 $\mathrm{mM}$ at $\mathrm{pH} 7.4$ and $38{ }^{\circ} \mathrm{C}$. Ammonium molybdate $(0.5 \mathrm{~mL})$ at $32.4 \mathrm{mM}$ was added after 4 minutes to stop the reaction. A blank test was done for each sample, with the same reaction, without the incubation period. The yellow complex of molybdate and $\mathrm{H}_{2} \mathrm{O}_{2}$ was measured using the spectrophotometric method with a wavelength of $405 \mathrm{~nm}$. The difference in absorbance between the blank and the incubated sample indicated the amount of $\mathrm{H}_{2} \mathrm{O}_{2}$ used by the enzyme. The $\mathrm{H}_{2} \mathrm{O}_{2}$ was determined using the coefficient of extinction $\epsilon=$ $0.0655 \mathrm{mM}^{-1} \mathrm{~cm}^{-1}$, and the result was expressed in umol $\mathrm{min}^{-1} \mathrm{mg}^{-1}$ protein.

Lipoxygenase (E.C. 1.13.11.12) was evaluated by absorbance at $234 \mathrm{~nm}$ in sodium linoleate at $10 \mathrm{mmol} \mathrm{L}^{-1}$ and $\mathrm{pH} 9.0$ as substrate, in a reaction mixture consisted of $1.000 \mu \mathrm{L}$ of sodium phosphate $50 \mathrm{Mmol} \mathrm{L}^{-1}, \mathrm{pH} 6.0,20 \mu \mathrm{L}$ of the linoleate substrate, and $10 \mu \mathrm{L}$ of the enzymatic extract, according to Silva et al. (2004). The coefficient of molar extinction $(\varepsilon)$ of hydroperoxide for the acid linoleic was $25,000 \mathrm{~mol} \mathrm{~L}^{-1} \mathrm{~cm}^{-1}$ at $\mathrm{pH}$ 6.0. The lipoxygenase specific activity was express in $\mu \mathrm{mol}$ of hydroperoxide of acid linoleic $\mathrm{min}^{-1} \mathrm{mg}^{-1}$ protein.

The peroxidase guaiacol activity (EC 
1.11.1.7) was determined at $30{ }^{\circ} \mathrm{C}$, using the spectrophotometric method, by measuring the conversion of guaiacol into tetra-guaiacol at $470 \mathrm{~nm}$ (LUSSO; PASCHOLATI, 1999). The enzymatic extract $(0.20 \mathrm{~mL})$ was mixed in $2.8 \mathrm{~mL}$ of a solution with $250 \mu \mathrm{L}$ of guaiacol, $306 \mu \mathrm{L}$ of $\mathrm{H}_{2} \mathrm{O}_{2}$, and 100 $\mathrm{mL}$ of phosphate buffer $0.01 \mathrm{M}(\mathrm{pH} 6.0)$. The activity was analyzed for 2 minutes, and the effective determination was the difference between the readings at 90 and 30 seconds. The results were expressed in absorbance $\mathrm{min}^{-1} \mu \mathrm{mg}^{-1}$ of protein.

The polyphenol oxidase activity (EC 1.10.3.2) was determined using the method described by Duangmal and Apenten (1999). The substrate (catecol at $20 \mathrm{mM}$, dissolved in potassium phosphate buffer $100 \mathrm{mM}$ at $\mathrm{pH}$ 6.8) was maintained in water bath at $30^{\circ} \mathrm{C} ; 100 \mu \mathrm{L}$ was added to a cuvette +900 $\mu \mathrm{L}$ of the enzymatic extract, with subsequent readings in a spectrophotometer at $420 \mathrm{~nm}$, directly, for two minutes. The difference between the reading after one minute and the initial reading was used to determine the activity. The results were expressed in absorbance $\min ^{-1} \mathrm{mg}^{-1}$ of protein.

The data were subjected to analysis of variance and, when significant, compared by the Scott-Knott test $(p>0.05)$.

\section{RESULTS AND DISCUSSION}

The application of $S$. bicolor (SBI) filtrate decreased the AUDPC in $80.75 \%$ and $96.13 \%$ in the third and fourth leaves, respectively, when compared to the control (Figure 1). When compared to ASM, which is the inducer recommended for the crop, the application of $S B I$ filtrate decreased the AUDPC in $42.4 \%$ and $8.8 \%$ in the third and fourth leaves, respectively (Figure 1).

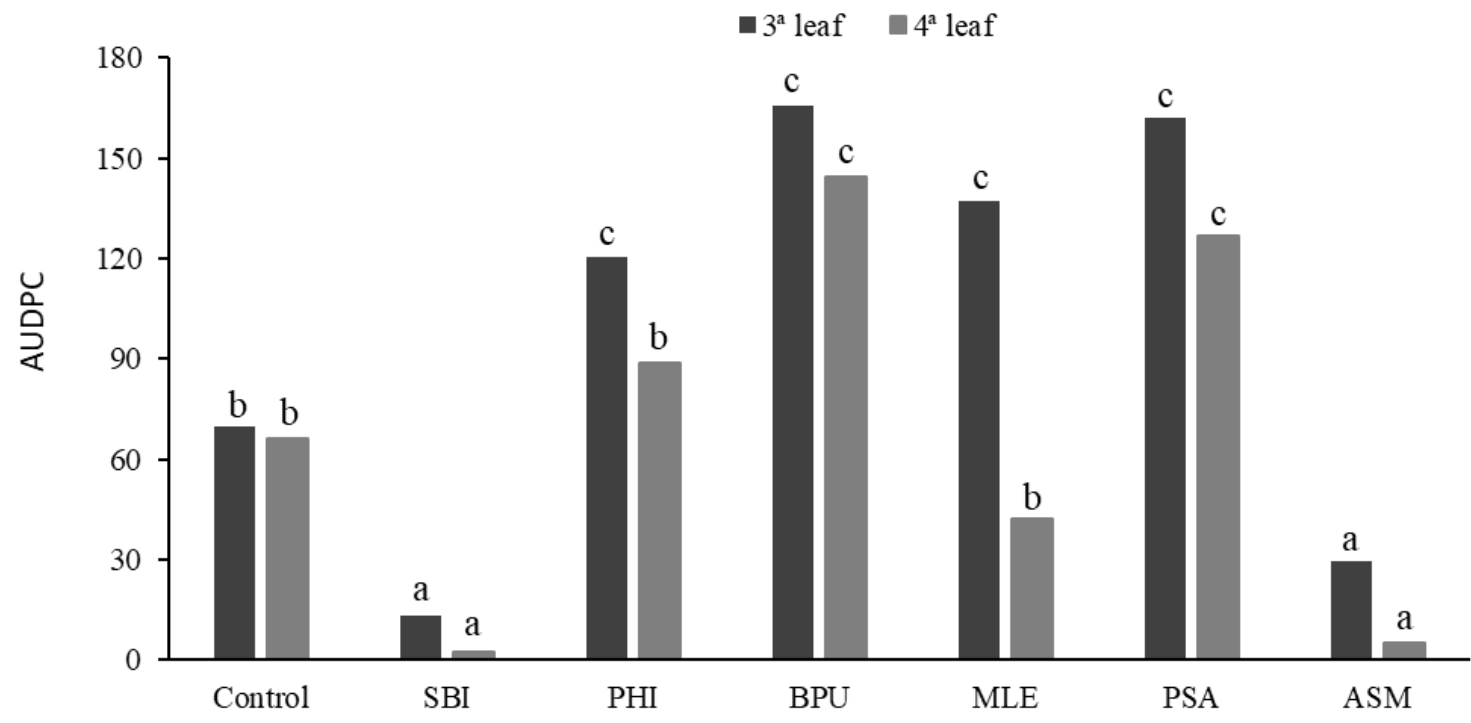

Means followed by the same letter in the bars are not different by the Scott-Knott test $(p<0.05)$. SBI $=$ Stachylidium bicolor, $P H I=$ Periconia hispidula, $B P U=$ Brachysporiella pulchra, $M L E=$ Myrothecium leucotrichum, and PSA = Pycnoporus sanguineus; ASM = acibenzolar-S-methyl.

Figure 1. Area under the disease progress curve (AUDPC) for early blight in the third and fourth leaves of tomato plants as a function of treatments with saprobic fungi filtrate at concentration of $20 \%$, at 3 days before the inoculation.

The application of $B$. pulchra increased the catalase activity in $240 \%$ at 48 hours postinoculation (hpi) when compared to the control. A peak was found at 96 hpi, when the mean activity was $39 \%$ higher than that of the control. The application of $P$. hispidula $(P H I)$ increased the catalase activity in $39 \%$ at 96 hpi; similar result was found for the response to the application of ASM (Table 2). The $P$. sanguineus (PSA) filtrate increased the catalase activity in $16 \%$ at 96 hpi when compared the control. 
M. S. R. ALENCAR et al.

Table 2. Catalase specific activity in tomato leaves treated with saprobic fungi filtrate and inoculated with Alternaria solani.

\begin{tabular}{|c|c|c|c|c|c|c|}
\hline \multirow{3}{*}{ Treatments } & \multicolumn{6}{|c|}{ Collection time (hours post-inoculation) } \\
\hline & 0 & 24 & 48 & 72 & 96 & 120 \\
\hline & \multicolumn{6}{|c|}{$\mu \mathrm{mol} \mathrm{min}{ }^{-1} \mathrm{mg}^{-1}$ protein } \\
\hline Control & $11.39 \mathrm{a}$ & $10.25 \mathrm{a}$ & $6.70 \mathrm{~b}$ & $8.65 \mathrm{a}$ & $8.48 \mathrm{~b}$ & $11.16 \mathrm{a}$ \\
\hline$S B I$ & $10.55 \mathrm{a}$ & $10.54 \mathrm{a}$ & $8.21 \mathrm{~b}$ & $9.12 \mathrm{a}$ & $6.24 \mathrm{~b}$ & $12.53 \mathrm{a}$ \\
\hline PHI & $13.18 \mathrm{a}$ & $8.66 \mathrm{a}$ & $9.20 \mathrm{~b}$ & $10.61 \mathrm{a}$ & $11.79 \mathrm{a}$ & $6.43 \mathrm{~b}$ \\
\hline$B P U$ & $13.15 \mathrm{a}$ & $11.44 \mathrm{a}$ & $22.80 \mathrm{a}$ & $11.77 \mathrm{a}$ & $11.86 \mathrm{a}$ & $12.97 \mathrm{a}$ \\
\hline$M L E$ & $12.07 \mathrm{a}$ & $10.85 \mathrm{a}$ & $5.64 \mathrm{~b}$ & $7.14 \mathrm{a}$ & $7.27 \mathrm{~b}$ & $13.22 \mathrm{a}$ \\
\hline$P S A$ & $11.99 \mathrm{a}$ & $8.02 \mathrm{a}$ & $11.10 \mathrm{~b}$ & $6.83 \mathrm{a}$ & $9.91 \mathrm{a}$ & $14.08 \mathrm{a}$ \\
\hline ASM & $11.43 \mathrm{a}$ & $11.89 \mathrm{a}$ & $6.76 \mathrm{~b}$ & $8.56 \mathrm{a}$ & $10.58 \mathrm{a}$ & $9.37 \mathrm{~b}$ \\
\hline $\mathrm{CV} \%$ & 40.89 & 25.38 & 92.23 & 38.60 & 19.10 & 24.21 \\
\hline
\end{tabular}

Means followed by the same letter in the columns are not different by the Scott-Knott test $(p<0.05)$. SBI = Stachylidium bicolor, $P H I=$ Periconia hispidula, BPU = Brachysporiella pulchra, MLE $=$ Myrothecium leucotrichum, and PSA = Pycnoporus sanguineus; ASM = acibenzolar-S-methyl.

The lipoxygenase activity increased in $130 \%$, $130 \%, 81 \%$, and $72 \%$ at $24 \mathrm{hpi}$ for the treatments SBI, MLE, ASM, and PHI, respectively, when compared to the control (Table 3). It increased in
$47 \%$ at $96 \mathrm{hpi}$ for the application of $\mathrm{PHI}$; and in $30 \%, 26 \%, 22 \%$, and $12 \%$ at $120 \mathrm{hpi}$, respectively, for the application of $S B I, B P U, P S A$, and $M L E$ filtrates.

Table 3. Lipoxygenase specific activity in tomato leaves treated with saprobic fungi filtrate and inoculated with Alternaria solani.

\begin{tabular}{|c|c|c|c|c|c|c|}
\hline \multirow{3}{*}{ Treatments } & \multicolumn{6}{|c|}{ Collection time (hours post-inoculation) } \\
\hline & 0 & 24 & 48 & 72 & 96 & 120 \\
\hline & \multicolumn{6}{|c|}{$\mu \mathrm{mol}$ of hydroperoxide of linoleic acid $\mathrm{min}^{-1} \mathrm{mg}^{-1}$ protein } \\
\hline Control & $3.16 \mathrm{a}$ & $2.11 \mathrm{~b}$ & $2.64 \mathrm{a}$ & $3.92 \mathrm{a}$ & $4.52 \mathrm{~b}$ & $5.80 \mathrm{~b}$ \\
\hline$S B I$ & $3.34 \mathrm{a}$ & $4.86 \mathrm{a}$ & $3.05 \mathrm{a}$ & $3.89 \mathrm{a}$ & $3.24 \mathrm{~b}$ & $7.59 \mathrm{a}$ \\
\hline PHI & $4.24 \mathrm{a}$ & $3.65 \mathrm{a}$ & $3.22 \mathrm{a}$ & $5.26 \mathrm{a}$ & $6.68 \mathrm{a}$ & $4.21 \mathrm{~b}$ \\
\hline$B P U$ & $6.18 \mathrm{a}$ & $1.45 \mathrm{~b}$ & $1.01 \mathrm{a}$ & $5.27 \mathrm{a}$ & $5.52 \mathrm{~b}$ & $7.34 \mathrm{a}$ \\
\hline$M L E$ & $3.81 \mathrm{a}$ & $4.60 \mathrm{a}$ & $1.94 \mathrm{a}$ & $4.12 \mathrm{a}$ & $3.32 \mathrm{c}$ & $6.51 \mathrm{a}$ \\
\hline$P S A$ & $3.73 \mathrm{a}$ & $2.54 \mathrm{~b}$ & $2.64 \mathrm{a}$ & $3.19 \mathrm{a}$ & $4.79 \mathrm{~b}$ & $7.10 \mathrm{a}$ \\
\hline ASM & $3.84 \mathrm{a}$ & $3.83 \mathrm{a}$ & $2.67 \mathrm{a}$ & $3.90 \mathrm{a}$ & $4.79 \mathrm{~b}$ & $4.62 \mathrm{~b}$ \\
\hline CV\% & 51.16 & 26.24 & 113.31 & 39.07 & 18.89 & 19.40 \\
\hline
\end{tabular}

Means followed by the same letter in the columns are not different by the Scott-Knott test $(p<0.05)$. SBI $=$ Stachylidium bicolor, $P H I=$ Periconia hispidula, BPU = Brachysporiella pulchra, MLE $=$ Myrothecium leucotrichum, and PSA = Pycnoporus sanguineus; ASM = acibenzolar-S-methyl.

The peroxidase guaiacol activity was not affected by the treatments, except $S B I$ at $120 \mathrm{hpi}$, which increased it in $74 \%$, when compared to the control (Table 4).

Table 4. Peroxidase specific activity in tomato leaves treated with saprobic fungi filtrate and inoculated with Alternaria solani.

\begin{tabular}{|c|c|c|c|c|c|c|}
\hline \multirow{3}{*}{ Treatments } & \multicolumn{6}{|c|}{ Collection time (hours post-inoculation) } \\
\hline & 0 & 24 & 48 & 72 & 96 & 120 \\
\hline & \multicolumn{6}{|c|}{ Absorbance $\min ^{-1} \mathrm{mg}^{-1}$ protein } \\
\hline Control & $1.94 \mathrm{a}$ & $1.89 \mathrm{a}$ & $1.57 \mathrm{a}$ & $2.43 \mathrm{a}$ & $2.05 \mathrm{a}$ & $2.23 \mathrm{~b}$ \\
\hline$S B I$ & $2.33 \mathrm{a}$ & $3.24 \mathrm{a}$ & $2.24 \mathrm{a}$ & $2.88 \mathrm{a}$ & $2.68 \mathrm{a}$ & $3.89 \mathrm{a}$ \\
\hline PHI & $1.97 \mathrm{a}$ & $2.26 \mathrm{a}$ & $1.67 \mathrm{a}$ & $2.29 \mathrm{a}$ & $1.99 \mathrm{a}$ & $1.88 \mathrm{~b}$ \\
\hline$B P U$ & $1.55 \mathrm{a}$ & $2.74 \mathrm{a}$ & $4.94 \mathrm{a}$ & $2.24 \mathrm{a}$ & $2.30 \mathrm{a}$ & $1.81 \mathrm{~b}$ \\
\hline$M L E$ & $1.60 \mathrm{a}$ & $2.41 \mathrm{a}$ & $1.93 \mathrm{a}$ & $2.15 \mathrm{a}$ & $2.31 \mathrm{a}$ & $2.71 \mathrm{~b}$ \\
\hline$P S A$ & $1.60 \mathrm{a}$ & $1.71 \mathrm{a}$ & $3.07 \mathrm{a}$ & $1.89 \mathrm{a}$ & $1.85 \mathrm{a}$ & $2.13 \mathrm{~b}$ \\
\hline ASM & $1.54 \mathrm{a}$ & $2.94 \mathrm{a}$ & $1.87 \mathrm{a}$ & $2.19 \mathrm{a}$ & $2.57 \mathrm{a}$ & $2.72 \mathrm{~b}$ \\
\hline $\mathrm{CV} \%$ & 48.98 & 32.26 & 92.74 & 32.52 & 24.10 & 28.53 \\
\hline
\end{tabular}

Means followed by the same letter in the columns are not different by the Scott-Knott test $(p<0.05)$. SBI $=$ Stachylidium bicolor, $P H I=$ Periconia hispidula, BPU = Brachysporiella pulchra, MLE $=$ Myrothecium leucotrichum, and PSA $=$ Pycnoporus sanguineus; ASM = acibenzolar-S-methyl. 
The polyphenol oxidase activity was not affected by the treatments in none of the collection times evaluated.

The $S B I$ filtrate probably presented molecules at enough concentration to activate defense mechanisms in tomato plants or acted directly on the pathogen, controlling the disease, presenting superior result to that found for the commercial product (ASM) indicated for the control of the disease by activation of latent resistance. Direct control involves the production of secondary metabolites that are toxic to phytopathogens, such as antibiotics and lytic enzymes produced by microorganisms that inhibit or delay their development (RUKACHAISIRIKUL et al., 2008; YANG et al., 2010; BETTIOL; MORANDI, 2009). In the case of induction of resistance, it is the recognizing of a elicitor agent that can generate a signaling cascade, starting with oxidative explosion, followed by accumulation of secondary compounds, and activation of defense genes and biochemical and morphological responses of the plant against environmental stress and attack by insects and phytopathogens (THAKUR et al., 2019; DUBERY; SANABRIA; HUANG, 2012).

Decreases in growth of early blight in tomato plants due to the application of $S$. bicolor can be attributed to releases of antagonist metabolites during the growth in liquid medium. The medium with the pathogen to be diluted and sprayed at $20 \%$ before inoculation can act as a protector barrier. Barros et al. (2015) evaluated the antigenic potential of saprobic fungi (Myrothecium sp., Pithomyces chartarum, Stachybotrys globosa, Memnoniella echinata, $M$. levispora and $S$. bicolor) against Sclerotinia sclerotiorum and found delays in their mycelial growth, indicating a direct control action of the phytopathogens. Barros et al. (2015) also conducted $\mathrm{a}$ in vivo evaluation and found that Myrothecium sp. and S. bicolor filtrates can decrease the diameter of lesions in soybean plant stems caused by $S$. sclerotiorum in up to $70 \%$ and $18 \%$, respectively, indicating a biocontrol action of these microorganisms.

The application of $P$. hispidula (PHI), B. pulchra $(B P U)$, and M. leucotrichum (MLE) filtrates increased the AUDPC when compared the control. This increase in lesioned area by the pathogen under these treatments can be related to the absence or low concentration of molecules with biological activity that can induce the activation of defense mechanisms in tomato plants; in addition, the sugar in the growth medium (batata and dextrose medium) affects saprobic fungi. High concentrations of proteins and carbohydrates in the filtrate composition could act as a nutritional source, favoring the pathogen growth, as described by Fiori-Tutida et al. (2007), who found increases in mycelial growth and germination of Bipolaris sorakiniana treated with Lentinula edodes filtrate.
Sensitive effects to tomato plants by application of saprobic fungi filtrates (Choloridium viresccens var. virescens, Sarcopodim circinatum, Dictiocheta heteroderae, Phialomyces macrosporus, and Stachybotrys chartarum) were described by Oliveira et al. (2013), who found significant increases in severity of early blight and attributed it to the nutritional composition of the filtrate.

The high control rates found for the treatments $S B I$ and ASM can be attributed, among other reasons, to their effect of induction of accumulation of reactive oxygen species, which was evidenced by the activation of enzymes related to oxidative stress (catalase, peroxidase, and lipoxygenase). The accumulation of reactive oxygen species can participate in processes of defense with toxic effect to pathogens, in hypersensitivity reactions, and as secondary signaling agents in the cascade of transduction of signals for activation of defense genes and cell protection (RESENDE; SALGADO; CHAVES, 2003), and can be a response mechanism (peroxidase activation) of plants to the $A$. solani infection when these plants were treated with SBI.

The catalase, peroxidase, and lipoxygenase enzyme activity analyses indicated that the saprobic fungi filtrate used has some molecule with elicitor potential in its constitution, which can be from protein, toxin, and oligosaccharide origin or from other components present or produced by microorganisms that signalize the functioning of the primary defense machinery in tomato plants (BITTEL; ROBATZEK, 2007; DUBERY; SANABRIA; HUANG., 2012).

\section{CONCLUSIONS}

Stachylidium bicolor filtrate is efficient to control the severity of the early blight disease in tomato plants.

The application of $S$. bicolor, Periconia hispidula, Brachysporiella pulchra, Myrothecium leucotrichum, and Pycnoporus sanguineus filtrates on tomato plants significantly increases the activity of the catalase, peroxidase, and lipoxygenase enzymes.

\section{ACKNOWLEDGEMENTS}

The authors thank Luís P. Gusmão for providing the saprobic fungi of the Biodiversity Research Program (PPBio); the CNPq for granting master's and doctoral scholarships to the researchers involved in this project; and the São Paulo Research Foundation (FAPESP) for financing the project. 


\section{REFERENCES}

AMORIM, L et al. Manual de fitopatologia: doenças das plantas cultivadas. 5. ed. São Paulo: Editora Agronômica Ceres, 2011. v. 2, 704 p.

BAE, S. J. et al. Trichoderma metabolites as biological control agents against Phytophthora pathogens. Biological Control, 92: 128-138, 2016.

BALBI-PEÑA, M. I; SCHWAN-ESTRADA, K. R. F.; STANGARLIN, J. R. Oxidative burst and the activity of defense-related enzymes incompatible and incompatible tomato-Alternaria solani interactions. Semina: Ciências Agrárias, 35: 2399-2414, 2014

BARROS, D. C. M. et al. Biocontrol of Sclerotinia sclerotiorum and white mold of soybean using saprobic fungi from semi-arid areas of Northeastern Brazil. Summa Phytopathologica, 41: 251-255, 2015.

BETTIOL, W.; MORANDI, F. A. B. Biocontrole de doenças de plantas: uso e perspectivas. 1. ed. Jaguariúna: Embrapa Meio Ambiente, 2009. v. 1, $345 \mathrm{p}$.

BITTEL, P.; ROBATZEK, S. Microbe-associated molecular patterns (MAMPs) probe plant immunity. Current Opinion in Plant Biology, 10: 335-341, 2007.

BOFF, P. Epidemiologia e controle químico da mancha de estenfílio (Stemphylium solani Weber) e da pinta preta (Alternaria solani) em dois sistemas de condução do tomateiro (Lycopersicon esculentum Mill). 1988. 192 f. Dissertação (Mestrado em Agronomia: Área de Concentração em Fitopatologia) - Universidade Federal de Viçosa, Viçosa, 1988.

BRADFORD, M. M. A rapid and sensitive method for the quantitation of microgram quantities of protein utilizing the principle of protein-dye binding. Analytical Biochemistry, 72, 248-254, 1976.

BRENT, R. J. Fungicide resistance in crop pathogens: How can it be managed? $2^{\mathrm{a}}$ ed, Belgium: Fungicide Resistance Action Commitee, 2007. 60 p.

CAMPBELL, C. L.; MADDEN, L. V. Introduction to Plant Disease Epidemiology. 1. ed. New York, NY: Wiley \& Sons, 1990. v. 1.560 p.

DEISING, H. B.; REIMANN, S.; PASCHOLATI, S. F. Mechanisms and significance of fungicide resistance. Brazilian Journal of Phytopathology, 39: 286-295, 2008.

DUANGMAL, K.; APENTEN, R. K. O. A comparative study of polyphenoloxidases from taro (Colocasia esculenta) e potato (Solanum tuberosum var. Romano). Food Chemistry, 64: 351-359, 1999.

DUBERY, I. A et al. Nonself perception in plant innate immunity. In: LOPES-LARREA, C. (Ed.). Self and noself. Johannesburg, Gauteng: Landes Bioscience and Springer Science, 2012. v. 1, chap. 6, p. 79-107.

Food and Agriculture Organization of the United Nations - FAOSTAT. Food and Agricultural commodities production. 2019. Disponível em: $<$ http://www.fao.org/faostat/en/\#rankings/ commodities_by_country>. Acesso em: 08 jul. 2019.

FIORI-TUTIDA, A. C. G. et al. Extratos de Lentinula edodes e Agaricus blazei sobre Bipolaris sorokiniana e Puccinia recondita f. sp. tritici, in vitro. Summa Phytopathologica, 33: 287-289, 2007.

FISHER, M. C. et al. Worldwide emergence of resistance to antifungal drugs challenges human health and food security. Science, 360: 739-742, 2018 .

FONSECA, F.et al. Percepção de risco: maneiras de pensar e agir no manejo de agrotóxicos. Ciência \& Saúde Coletiva, 12: 39-50, 2007.

GOTH, L. A simple method for determination of serum catalase activity and revision of reference range. Clinica Chimica Acta, 196: 143-151, 1991.

HAMMERSCHMIDT, R.; MÉTRAUX, J. P.; VAN LOON, L. C. Inducing resistance: a summary of papers presented at the first international Symposium on induced resistance to plant diseases, corfu. Europen Journal Plant of Pathology, 107: 1-6, 2001

JONES, J. P. Early blight. In: JONES, J. B.; JONES, J. P.; STALL, R. E. (Eds.). Compendium of tomato diseases. St. Paul, MN: APS Press. 1991. v. 1, chap. 1, p. 13-14.

KIRÁLY， L.; BARNA，B.; KIRÁLY，Z. Plant resistance to pathogen infection: forms and mechanisms of innate and acquired resistance. Journal of Phytopathology, 155: 385-396, 2007.

LANDSCHOOT, S. et al. Boscalid-resistance in Alternaria alternata and Alternaria solani populations: An emerging problem in Europe. Crop Protection, 92: 49-59, 2017.

LUSSO, M. F. G.; PASCHOLATI, S. F. Activity and isoenzymatic pattern of soluble peroxidases in maize tissues after mechanical injury or fungal 
inoculation. Summa Phytopathologica, 25: 244249, 1999.

OLIVEIRA, J. S. B. et al. Indução de crescimento e controle da pinta preta em tomateiro. In: ENCONTRO INTERNACIONAL DE PRODUÇÃO CIENTÍFICA CESUMAR - EPCC, 8, 2013, Maringá. Anais... Maringá: Editora CESUMAR, 2013. P. 1-4.

PAZUCH, D. Potencial indutor de fitoalexinas do filtrado de cultura e extrato de basiocarpo e de micélio de $P$. sanguineus em sorgo e soja. 2007, 37 f. Trabalho de conclusão de curso (Graduação em Agronomia), Universidade Estadual do Oeste do Paraná, Marechal Cândido Rondon, 2007.

PEITL, D. C. et al. Biological control of tomato bacterial spot by saprobe fungi from semi-arid areas of northeastern Brazil. Semina: Ciências Agrárias, 38: 1251-1263, 2017.

RESENDE, M. L. V.; SALGADO, S. M. L.; CHAVES, Z. M. Espécies ativas de oxigênio na resposta de defesa de plantas a patógenos. Fitopatologia Brasileira, 28: 123-130, 2003.

RUKACHAISIRIKUL, V. et al. Metabolites from the endophytic fungus Phomopsis sp. PSU-D15. Phytochemistry, 69: 783-787, 2008.

SILVA, H. S. A. et al. Rhizobacteria induction of systemic resistance in tomato plants: non-specific protection and increase in enzyme activies. Biological Control, 29: 288-295, 2004.

SOLINO, A. J. et al. Induction of defense mechanisms from filtrates of saprophytic fungi against early blight disease in tomato. African Journal of Microbiology Research, 10: 1849-1859, 2016.

THAKUR, M. et al. Improving production of plant secondary metabolites through biotic and abiotic elicitation. Journal of Applied Research on Medicinal and Aromatic Plants, 12: 1-12, 2019.

TOMÁNKOVÁ, K. et al. Biochemical aspects of reactive oxygen species formation in the interaction between Lycopersicon spp. and Oidium neolycopersici. Physiological and Molecular Plant Pathology, 68: 22-32, 2006.

WALTERS, D. R; RATSEP, J.; HAVIS, N. D. Controlling crop diseases using induced resistance: challenges for the future. Journal of Experimental Botany, 64: 1263-1280, 2013.

YANG, J. X. el al. Metabolites from the mangrove endophytic fungus Phomopsis sp (\#zsu-H76). European Journal Organic Chemistry, 19: 3692369, 2010.

ZEILINGER, S. et al. Secondary metabolism in Trichoderma - chemistry meets genomics. Fungal Biology Reviews, 30: 74-90, 2016. 